\title{
Estate Planning: Preparing a Letter of Last Instructions ${ }^{1}$
}

\author{
Josephine Turner
}

A letter of last instructions is an informal document, and one of the most helpful things you can provide for your family. The letter should express your wishes following your death. The purpose of this letter is to give your personal representative or family member the information he or she will need concerning your personal and financial matters.

You don't need an attorney to prepare it. Although this letter does not carry the legal weight of a will, it is very important because it clarifies requests to be carried out after your death. The letter provides essential information needed by the surviving family members thereby relieving them of needless worry. Your family will be grateful for this information.

When writing your letter of last instruction use the following list as a guide and provide detail information to include: names, addresses, and telephone numbers.

\section{Notification}

Prepare a list of people to notify of your death. Include family members, acquaintances, and organizations. Also include professionals, your accountant, attorney, broker, employer, executor, financial institutions, insurance agents, newspapers to receive obituary information, Social Security Office (include Social Security Number and location of
Social Security card), and the U.S. Department of Veterans Affairs, if appropriate.

\section{Funeral Arrangements}

Describe the arrangements you have already made and those that your family must make. Specify your wishes on the following (If pre-arrangements have been made give details.):

1. Organ donations

2. Autopsy if requested

3. Embalming

4. Public viewing

5. Body disposal(detail any arrangements made)

- remains donated

- cremated (disposal of ashes)

- burial and location

6. Type of service and location

7. Funeral (open casket, closed)

8. Memorial

9. Flowers and/or donations (to whom)

10. Where, specify memorial gifts or flowers.

List the number of death certificates that will be needed, usually six to 12 are needed. The funeral director or cremation service director will order as many death certificates as you request. The following

1. This document is FCS5238, one of a series of the Department of Family, Youth and Community Sciences, Florida Cooperative Extension Service, IFAS, University of Florida. Publication : December 2002. Reviewed by: Mary N. Harrison, professor of Consumer Education, FYCS; Gary E. Pleiss, FCS agent, Pinellas County Extension; Dena K. Wise, associate professor and Family Economic specialist University of Tennessee. Please visit the EDIS Web site at http://edis.ifas.ufl.edu

2. Josephine Turner, CFP, Ph.D., professor of Family and Consumer Economics, Department of Family, Youth and Community Sciences, Cooperative Extension Service, IFAS, University of Florida, Gainesville, 32611.

The Institute of Food and Agricultural Sciences is an equal opportunity/affirmative action employer authorized to provide research, educational information and other services only to individuals and institutions that function without regard to race, color, sex, age, handicap, or national origin. For information on obtaining other extension publications, contact your county Cooperative Extension Service office. Florida Cooperative Extension Service / Institute of Food and Agricultural Sciences / University of Florida / Christine Taylor Waddill, Dean 
is a list of institutions that will probably want a certified copy of the death certificate:

- Insurance companies (each company that insured the individual or his property will want a copy)

- Financial institutions (banks, credit unions, mortgage companies, brokerage firms, credit card companies)

- Pension fund(s)

- IRS

- Social Security Administration

- The Circuit court in each county where the deceased owned real property

Pull together information the funeral director will need such as:

- your full name

- address

- marital status

- spouse's name

- date of birth

- birthplace

- father's and mother's names and birthplaces

- name of next of kin (other than spouse)

- length of residence in state and in United States

- military records/history

- Social Security number

- occupation

- life insurance information

\section{Personal Papers}

In your letter give the location of all of your personal documents including your will, birth, baptismal and marriage certificates, communion and confirmation certificates, diplomas, military papers, naturalization papers, and any other documents such as divorce or adoption papers.

\section{Automobiles}

Tell where the registration and other papers for your automobiles and titled property may be found.

\section{Bank Accounts}

List all your checking and savings accounts by name and institution, address of the office where the account is located, the type of account and the account number. Include the location of canceled checks and statements.

\section{Boxes}

Be sure to give the location of your safe deposit box, a list of the contents, and where the key is located. Also provide the location and number of any post office boxes that you have.Tell where the key may be found or give the combination of the box.

\section{Credit Cards}

List your credit cards by issuer and by card number. Request a copy of "Credit Card Safety Record" from your local county extension office or go on line at http://edis.ifas.ufl.edu/fy 378 to make this task easier.

\section{Debts Owed You}

Make a list of all the debts owed to you; include full name, address and telephone number of the debtor, payment terms, collateral, etc.

\section{Homeowner Records}

Give the location of the deed and mortgage papers on all property that you own. Provide information on taxes, liens, leases, etc.

\section{Household Contents}

List the contents of your house and location of household inventory, and appraisals. List the owners of all household items and what you want to happen to items you own.

\section{Insurance}

List all of your insurance policies by type (life, auto, home, veteran's medical, credit life), company name and address, policy number and insurance agent. Include a description of any loans that you have taken out against a policy and not yet repaid. Also include the location of each policy. 


\section{Investments}

Make a list of all stocks, bonds, and other securities by certificate number, issuers, and cost.Tell where the documents are located and identify stockbrokers with name, address and telephone numbers.

\section{Loans}

List all loans and other accounts that you must repay. Give full information on terms, payments, collateral, etc.

\section{Personal Effects}

Provide a list of your personal effects and who is to receive each. Include such detail as to the complete name, address and relationship of the person who will receive your golf clubs, gold watch, clothes, etc.

\section{Survivor's Benefits}

List possible sources of benefits such as Social Security, veteran's, employee, fraternal association, credit life insurance. Include amount or estimated amount that can be expected from each source.

\section{Taxes}

Include in your letter of last instructions the location of your income tax returns for the past five years.

\section{Trusts}

Make a list of all the trusts that you have established. Give the name and address of each trustee and identify the type and amount of assets in each trust.

\section{Other}

Provide the location of receipts, warranties, and other miscellaneous papers. Explain any unusual provisions of the will, such as disinheritance of a child or forgiveness of a debt.

Write your letter clearly so that even a stranger could understand it. Also be sure that your letter does not contradict your will. If you are in doubt check with your attorney. Since this letter describes your finances in detail give a copy of the letter to your personal representative and keep the original and copies in a safe place. Be sure to sign and date your letter of last instructions and don't keep it with your will.

\section{Acknowledgment}

Many thanks to Mr. Richard M. White, Jr., Florida Bar Certified in Wills, Trusts, and Estates, Gainesville, Florida, for reviewing this publication for accuracy. 